\title{
Comparing the Proximate Composition, Technological Properties and Sensory Attributes of Burger Patties and Emulsion Sausage Processed from Imported Brazilian and Indian Meat
}

\author{
Marwa A Hassan ${ }^{1}$, Hussein MH Mohamed ${ }^{1,2}$, Nabil A Yassien ${ }^{1}$ and Heba HS Abdel-Naeem ${ }^{1 *}$ \\ ${ }^{1}$ Department of Food Hygiene and Control, Faculty of Veterinary Medicine, Cairo University, Giza 12211, Egypt \\ ${ }^{2}$ Department of Technology and Natural Resources, Faculty of Applied Science and Technology, Universiti Tun Hussein \\ Onn Malaysia (UTHM), Johor, Malaysia \\ *Corresponding author: h.hussein@cu.edu.eg; dr_hoba.h106@yahoo.com
}

Article History: 20-090 Received: April 03, $2020 \quad$ Revised: May 20,2020 Accepted: June 09,2020
ABSTRA CT
This study was conducted to compare the technological properties of burger patties and emulsion sausages processed from
imported Brazilian and Indian meat. Burger patties and emulsion sausage were processed from these meat and the
processed products were analyzed for proximate chemical analysis, deterioration criteria, instrumental color, shear force,
sensory attributes, cooking characteristics for burger patties, and emulsion stability for the emulsion sausage. The results
revealed that using imported Brazilian chuck meat in processing of burger patties and emulsion sausage resulted in
significant increase in L* values, moisture content, sensory attribute and significant decrease of a* values and shear force
values and non-significant change of deterioration criteria. There were non-significant changes in cooking characteristics
of the burger patties processed from imported Brazilian or Indian meat however; higher emulsion stability in emulsion
sausage processed from imported Brazilian meat was observed. Therefore, Indian meat can be used in meat processing
after Brazilian meat which may give chance to the producers to formulate good quality products from lower price meat
source.

Key words: Burger patties, Emulsion sausage, Technological properties, Indian, Brazilian.

\section{INTRODUCTION}

Burger is the most widely consumed meat products as fast meals in the world including Arab countries to fulfill consumer's demands. In addition, emulsion type sausages are widely used in different countries especially as sources of ready to eat meat products. Meat emulsions are one of the highest price meat products due to their processing from high cost lean meat. Moreover, the recipes should be adaptable to wide variation in raw materials and formulated to satisfy a variety of purposes, including legal/regulatory requirements, information for costing, quality control and consistent product standards (Ranken, 2000).

One of the essential elements that are important in manufacturing of successful meat products is selection of proper raw meat material with good technological properties. Therefore, choosing the suitable raw meat material of reasonable price is a challenging process for meat processors. The national meat industry requires good raw meat material to meet high quality parameters of the processed products. Imported Brazilian beef is the most popular raw meat material that is used for processing of different meat products in Egypt. However, meat processors are directed for utilization of imported buffalo meat from India as alternative due to its availability at low cost. Increasing the use of buffalo's meat in processing is due to its higher content of lean and protein (Gracey et al., 1999). Moreover, the characteristic dark color of buffalo meat gives good marbling appearance with fat particle which is very useful in processing of formed products.

Most of previous studies have focused on quality and safety of imported Brazilian meat (Alkhanky et al., 2015, Mohamed et al., 2017), while, studies on imported Indian meat quality still limited. Furthermore, there is no previous study comparing technological quality of meat products processed from imported Brazilian and Indian meat. Therefore, the goal of this study was to evaluate the suitability of Indian meat for processing through comparing the technological properties of burger patties and emulsion sausages processed from imported Brazilian and Indian meat. Moreover, meat processors are interested in keeping the quality of meat products during storage, therefore, processed meat products were stored and their quality parameters were assessed.

Cite This Article as: Hassan MA, HMH Mohamed, NA Yassien and HHS Abdel-Naeem, 2020. Comparing the proximate composition, technological properties and sensory attributes of burger patties and emulsion sausage processed from imported brazilian and indian meat. Int J Vet Sci, 9(3): 403-408. www.ijvets.com (@2020 IJVS. All rights reserved) 


\section{MATERIALS AND METHODS}

\section{The study design}

A triple replicate experiment was conducted to explore the impact of incorporating the imported Brazilian and Indian chuck meat on the physicochemical and sensory attributes of burger and emulsion sausage. The processed products were kept at $-18^{\circ} \mathrm{C}$ (burger) and at $4{ }^{\circ} \mathrm{C}$ (emulsion sausages) for 3 months and their quality was assessed monthly.

\section{Preparation of burger patties and emulsion sausage ingredients}

Imported Brazilian and Indian chucks meat of first $3^{\text {rd }}$ of its shelf life (five from each) were obtained from Cairo store and stored at $-18^{\circ} \mathrm{C}$ until processing. From Loba Chemie, India, seasonings mix, nitrite and polyphosphate salts were purchased while; from Cairo store in Egypt corn starch and common salt were purchased.

\section{Formulation of burger patties and emulsion sausage}

Burger patties formulation was: $62 \%$ imported Brazilian or Indian chucks meat, 5\% bread crump, $18 \%$ beef fat, $1.6 \%$ common salt, $0.3 \%$ sodium tripolyphosphate, $0.5 \%$ seasonings (cumin, coriander, mace and white pepper) and $13 \%$ water. While, luncheon sausage formulation was: $70 \%$ imported Brazilian or Indian meat chucks, $12 \%$ beef fat, $1.6 \%$ sodium chloride, $0.5 \%$ polyphosphates, $100 \mathrm{ppm}$ sodium nitrite, $5 \%$ corn starch, $10 \%$ iced water, and quantum sufficient of spice mix (coriander, mace, cardamom and white pepper).

\section{Burger patties and luncheon sausage processing}

For processing of burger patties, the imported Brazilian or Indian meat of each formula were partially thawed ($5^{\circ} \mathrm{C}$ ) and cutted into flakes by meat saw. Using coarse grinder plate (Seydelmann, Germany), the lean meat and fat were minced. Afterward the minced lean meat, fat particles, polyphosphates, sodium chloride, water, seasonings and bread crump were mixed together for 5 minutes. This mixture was shaped into $75 \mathrm{~g}$ and $1-\mathrm{cm}$ thickness patties using patties former with $9-\mathrm{cm}$ internal diameter. The burger patties were exposed to $-40^{\circ} \mathrm{C}$ for $30 \mathrm{~min}$, packaged and kept frozen at $-18^{\circ} \mathrm{C}$ for 3 months.

For processing the emulsion sausage, the imported Brazilian or Indian meat of each formula were partially thawed $\left(-5^{\circ} \mathrm{C}\right)$ and cutted into flakes by meat saw. By the coarse grinder plate (Seydelmann, Germany), the lean meat and fat were minced. The minced meat was chopped for short time with sodium tripolyphosphate, sodium chloride, and sodium nitrite before addition of cold water and fat. The meat batter was mixed after addition of starch at $1{ }^{\circ} \mathrm{C}$ and unloading the meat batter at temperature $8^{\circ} \mathrm{C}$. The meat batter was filled in polyamide casing using piston filler, and then cooked using humid cooking program at core temperatures $\left(70^{\circ} \mathrm{C}\right)$, cooled and kept at refrigerator at $4^{\circ} \mathrm{C}$ for 3 months.

\section{Burger patties and emulsion sausage investigations}

The proximate chemical analysis of processed burger patties and emulsion sausage as well as the emulsion stability of the emulsion sausage were measured at 0-time only. While, deterioration criteria, color, shear force (SF) and sensory attributes of both products and cooking characteristics of burger patties were investigated at 0 time and monthly for 3 months.

\section{Proximate chemical analysis}

Proximate chemical composition of burger and emulsion sausage produced from imported Brazilian or Indian chuck meat were analyzed after the processing (AOAC, 2000). For examination of moisture contents, $3 \mathrm{~g}$ from each sample were dried in oven at $100^{\circ} \mathrm{C}$ until obtaining fixed weight. Protein content was examined using Kjeldahl method and conversion factor (6.25) was used to convert nitrogen content into crude protein. A soxhlet apparatus was used to determine the fat content. Ash content of all samples was determined using muffle furnace by ignition at $500^{\circ} \mathrm{C}$ for $5 \mathrm{~h}$.

\section{Measurement of deterioration criteria}

Five grams from each burger patties and emulsion sausage produced from imported Brazilian or Indian chuck meat were homogenized for $10-15 \mathrm{~s}$ with $20 \mathrm{ml}$ distilled water to measure the $\mathrm{pH}$ value using a $\mathrm{pH}$ meter which has been previously calibrated using two buffers 7.0 and 4.0 (Kandeepan et al., 2009). Macro-Kjeldahl distillation was used to measure total volatile base nitrogen (TVBN) (Kearsley et al., 1983) while, thiobarbituric acid (TBA) was analyzed using the method of Du and Ahn (2002).

\section{Color estimation}

The color of burger patties and emulsion sausage produced from imported Brazilian or Indian chuck meat were measured by Croma meter (Konica, Japan). The lightness $\left(\mathrm{L}^{*}\right)$, redness $\left(\mathrm{a}^{*}\right)$, and yellowness $\left(\mathrm{b}^{*}\right)$ values were measured using light source of CIE illuminant $\mathrm{D}_{65}$. Three reading from each sample were measured and the average value was recorded after the method recommended by Shin et al. (2008).

\section{Measurement of shear force}

From each cooked burger patties and emulsion sausage produced from imported Brazilian or Indian chuck meat, four samples $(1 \times 1 \times 1 \mathrm{~cm})$ were cut. Three reading of the shear force (SF) value was measured using Instron Machine (USA) and the average value was calculated according to Shackelford et al. (2004).

\section{Sensory examination}

Sensory analysis of burger patties and luncheon sausage produced from imported Brazilian or Indian chuck meat was performed according to AMSA 1995. Five burger patties were taken from each formula and cooked in oven (Heraeus, Germany) at $180^{\circ} \mathrm{C}$ and a core temperature $75^{\circ} \mathrm{C}$. Three replicates from all treatments were evaluated by each panelist from both cooked burger patties and emulsion sausage. Each panelist evaluated each sample and give number from 1 (extremely unacceptable) to 8 (extremely acceptable) for the sensory attributes.

\section{Cooking characteristics}

Cooking characteristics includes moisture retention, fat retention, diameter reduction and cooking loss percentage of burger patties produced from imported Brazilian or Indian chuck meat were estimated according to the methods of El-Magoli et al. (1996), Murphy et al. (1975) and Serdaroğlu and Değirmencioğlu (2004). 


\section{Emulsion stability}

Emulsion stability of the emulsion sausage was determined according to the procedures of Hughes et al. (1997), with some modifications mentioned by Colmenero et al. (2005). Twenty-five grams of meat batter processed from imported Brazilian or Indian chuck meat were centrifuged at $6000 \mathrm{rpm}$ for 15 minutes, heated at $70^{\circ} \mathrm{C}$ for 60 minutes, and centrifuged once more at the same speed for 20 minutes. The tubes were left at room temperature for 50 minutes to separate the supernatant (Total Fluid Released, TFR) onto a pre-weighed crucible. TFR percentage was calculated from the original weight of sample. Heating the TFR in an oven at $105^{\circ} \mathrm{C}$ for 16 hours to record the water released (WR). Fat (FR) and gelatin released (GR) were estimated as the difference between TFR and WR while, the fat content was separated from gelatin by soxhlet apparatus.

\section{Statistical analysis}

SPSS 23.0 for windows (SPSS Inc., Chicago, IL, USA) was used to analyze all data and all values were recorded as mean $\pm \mathrm{SE}$. The one-way ANOVA test was used to compare between means and least-square difference test was used to detect the significance between means, which was considered at $P<0.05$.

\section{RESULTS AND DISCUSSION}

Table 1 summarized results of proximate chemical analysis of burger patties (raw and cooked) as well as emulsion sausage produced from imported Brazilian and Indian chuck meat. The moisture content was significantly $(\mathrm{P}<0.05)$ lower while, protein and fat content was significantly $(\mathrm{P}<0.05)$ higher with non-significant $(\mathrm{P}>0.05)$ change of ash content in burger patties (raw and cooked) as well as emulsion sausage processed from Indian meat as compared to the products processed from Brazilian meat. Alakali et al. (2010) and Kassem and Emara (2010) recorded lower protein and moisture contents and higher ash and fat contents of raw and cooked burger patties. Moreover, wide range of proximate chemical composition for the emulsion sausages was recorded (Elbazidy et al., 2017). This is may be attributed to the variation in lean and fat ratio, level of extenders and fillers used and processing temperature (Kdous et al., 2016). Meanwhile, the proximate chemical analysis was not affected by the machine used in the processing (Saad et al., 2016).

Deterioration criteria of burger patties during frozen storage and emulsion sausage during chilling storage were presented in Table (2). The $\mathrm{pH}, \mathrm{TVBN}$ and TBA values of burger patties processed form imported Brazilian meat showed non-significant $(\mathrm{P}>0.05)$ changes from those processed from Indian buffalo meat during the first month of storage. However, the significant $(\mathrm{P}<0.05)$ higher $\mathrm{pH}$ and TVBN values of burger patties processed from imported Brazilian meat were observed at the $2^{\text {nd }}$ and $3^{\text {rd }}$ months of storage. Meanwhile, the significant $(\mathrm{P}>0.05)$ lower TBA values of burger patties processed from imported Brazilian meat than those processed from Indian meat were noticed only at the $3^{\text {rd }}$ months of storage.

The gradual increasing of $\mathrm{pH}$ value, TVBN and TBA values of Brazilian patties stored at $-18^{\circ} \mathrm{C}$ for 3 months
Table 1: Proximate chemical composition of burger patties and emulsion sausage processed from imported Brazilian and Indian chuck meat

\begin{tabular}{lcc}
\hline Type of raw meat materials & Brazilian meat & Indian meat \\
\hline Raw burger patties & & \\
Moisture $(\mathrm{g} \%)$ & $77.66^{\mathrm{a}} \pm 1.34$ & $71.86^{\mathrm{b}} \pm 0.50$ \\
Protein $(\mathrm{g} \%)$ & $13.54^{\mathrm{a}} \pm 0.46$ & $16.46^{\mathrm{b}} \pm 0.93$ \\
Fat $(\mathrm{g} \%)$ & $14.20^{\mathrm{a}} \pm 0.16$ & $16.38^{\mathrm{b}} \pm 0.40$ \\
Ash $(\mathrm{g} \%)$ & $1.50^{\mathrm{a}} \pm 0.24$ & $1.95^{\mathrm{a}} \pm 0.04$ \\
Cooked burger patties & & \\
Moisture (g \%) & $73.16^{\mathrm{a}} \pm 0.25$ & $67.65^{\mathrm{b}} \pm 0.03$ \\
Protein $(\mathrm{g} \%)$ & $15.30^{\mathrm{a}} \pm 0.15$ & $17.00^{\mathrm{b}} \pm 0.029$ \\
Fat $(\mathrm{g} \%)$ & $15.39^{\mathrm{a}} \pm 0.20$ & $17.62^{\mathrm{b}} \pm 0.27$ \\
Ash $(\mathrm{g} \%)$ & $3.07^{\mathrm{a}} \pm 0.10$ & $3.70^{\mathrm{a}} \pm 0.55$ \\
Luncheon sausage & & \\
Moisture (g \%) & $67.43^{\mathrm{a}} \pm 0.04$ & $63.40^{\mathrm{b}} \pm 0.73$ \\
Protein (g \%) & $14.37^{\mathrm{a}} \pm 0.27$ & $16.02^{\mathrm{b}} \pm 0.14$ \\
Fat $(\mathrm{g} \%)$ & $15.70^{\mathrm{a}} \pm 0.04$ & $17.39^{\mathrm{b}} \pm 0.23$ \\
Ash (g \%) & $2.44^{\mathrm{a}} \pm 0.11$ & $2.51^{\mathrm{a}} \pm 0.05$ \\
\hline a-b Means with different & superscripts within the same row \\
significantly (P<0.05) different: * Values represent the mean \pm SE.
\end{tabular}

were observed by several authors (Abdel-Aziz and Morsy, 2015, Gahruie et al., 2017). The gradual increasing of $\mathrm{pH}$ value during freezing storage may be attributed to the growth of microorganisms which can change their environment $\mathrm{pH}$ by consuming acids and creating basic wastes (Bauman, 2005). $\mathrm{pH}$ and TBA values of emulsion sausages processed from imported Brazilian meat or Indian buffalo meat were non-significantly $(\mathrm{P}>0.05)$ differ at 0 -time and along the chilling storage. The nonsignificant $(\mathrm{P}>0.05)$ difference of TVBN values of Brazilian emulsion sausages was observed at 0 -time and during the $1^{\text {st }}$ month of storage, however, this value were significantly $(\mathrm{P}<0.05)$ lower at the $2^{\text {nd }}$ and $3^{\text {rd }}$ months of storage when compared with Indian emulsion sausages. Similar results of $\mathrm{pH}$ values were recorded by Selim et al. (2015) who found that $\mathrm{pH}$ values of emulsion sausage were ranged from 5.9 to 6.4 , and attributed these values to the addition of curing agents within emulsion sausage processing such as acidifiers and organic substances. This $\mathrm{pH}$ values is appropriate to quality and stability of the emulsion sausage meat color (Kdous et al., 2016). Elbazidy et al. (2017) observed significant increasing in $\mathrm{pH}$ value and non-significant changes in TVBN and TBA value of emulsion sausage processed from imported Brazilian meat.

$\mathrm{L}^{*}, \mathrm{a}^{*}$ and $\mathrm{b}^{*}$ values were non-significantly $(\mathrm{P}>0.05)$ differ between burger patties processed from imported Brazilian and Indian meat at 0-time. However, a significant $(\mathrm{P}<0.05)$ increase of $\mathrm{L}^{*}$ values and nonsignificant $(\mathrm{P}>0.05)$ changes in $\mathrm{a}^{*}$ and $\mathrm{b}^{*}$ values of burger patties processed from Brazilian meat as compared with burger patties processed from Indian meat were observed during frozen storage (Table 3). These results were in agreement with Uriyapongson (2007) who reported that fried beef patties had lighter inside color than those of buffalo burger patties at all frozen storage time. The color values of emulsion sausages processed from imported Brazilian meat revealed a significant $(\mathrm{P}<0.05)$ increase in $\mathrm{L}^{*}$, significant $(\mathrm{P}<0.05)$ decrease in $\mathrm{a}^{*}$ and nonsignificant $(\mathrm{P}>0.05)$ change of $\mathrm{b}^{*}$ values when compared with emulsion sausages processed from Indian meat at 0time and during chilling storage (Table 3). Elbazidy et al. (2017) observed that the $L^{*}, b^{*}$ and $a^{*}$ values of emulsion 
Int J Vet Sci, 2020, 9(3): 403-408.

Table 2: Deterioration criteria of burger patties and emulsion sausage processed from imported Brazilian and Indian chuck meat

\begin{tabular}{|c|c|c|c|c|c|c|c|c|}
\hline \multirow[t]{2}{*}{ Treatments } & \multicolumn{8}{|c|}{ Storage period (months) } \\
\hline & 0 -time & $1^{\text {st }}$ month & $2^{\text {nd }}$ month & $3^{\text {th }}$ month & 0 -time & $1^{\text {st }}$ month & $2^{\text {nd }}$ month & $3^{\text {th }}$ month \\
\hline & \multicolumn{3}{|c|}{ Burger patties $\left(-18^{\circ} \mathrm{C}\right)$} & \multicolumn{5}{|c|}{ Luncheon sausage $\left(4^{\circ} \mathrm{C}\right)$} \\
\hline $\mathrm{pH}$ & & & & & & & & \\
\hline Brazilian meat & $5.80^{\mathrm{a}} \pm 0.05$ & $5.96^{\mathrm{a}} \pm 0.03$ & $6.03^{\mathrm{a}} \pm 0.03$ & $6.10^{\mathrm{a}} \pm 0.03$ & $5.95^{\mathrm{a}} \pm 0.20$ & $6.05^{\mathrm{a}} \pm 0.30$ & $6.10^{\mathrm{a}} \pm 0.01$ & $6.24^{\mathrm{a}} \pm 0.01$ \\
\hline $\begin{array}{l}\text { Indian meat } \\
\text { TVBN (mg \%) }\end{array}$ & $5.66^{\mathrm{a}} \pm 0.06$ & $5.86^{\mathrm{a}} \pm 0.03$ & $5.86^{\mathrm{b}} \pm 0.03$ & $5.93^{\mathrm{b}} \pm 0.03$ & $5.91^{\mathrm{a}} \pm 0.10$ & $5.98^{\mathrm{a}} \pm 0.10$ & $6.08^{\mathrm{a}} \pm 0.01$ & $6.23^{\mathrm{a}} \pm 0.02$ \\
\hline Brazilian meat & $4.85^{\mathrm{a}} \pm 0.24$ & $5.69^{\mathrm{a}} \pm 0.40$ & $6.41^{\mathrm{a}} \pm 0.23$ & $7.36^{\mathrm{a}} \pm 0.23$ & $4.67^{\mathrm{a}} \pm 0.25$ & $5.51^{\mathrm{a}} \pm 0.25$ & $6.91^{\mathrm{a}} \pm 0.01$ & $8.67^{\mathrm{a}} \pm 0.22$ \\
\hline $\begin{array}{l}\text { Indian meat } \\
\text { TBA (mg / kg) }\end{array}$ & $5.04^{\mathrm{a}} \pm 0.32$ & $6.53^{\mathrm{a}} \pm 0.24$ & $7.64^{b} \pm 0.12$ & $9.32^{\mathrm{b}} \pm 0.54$ & $5.13^{\mathrm{a}} \pm 0.25$ & $5.94^{\mathrm{a}} \pm 0.15$ & $8.71^{\mathrm{b}} \pm 0.02$ & $9.94^{\mathrm{b}} \pm 0.36$ \\
\hline Brazilian meat & $0.11^{\mathrm{a}} \pm 0.01$ & $0.33^{\mathrm{a}} \pm 0.08$ & $0.60^{\mathrm{a}} \pm 0.04$ & $0.74^{\mathrm{a}} \pm 0.02$ & $0.30^{\mathrm{a}} \pm 0.02$ & $0.43^{\mathrm{a}} \pm 0.08$ & $0.52^{\mathrm{a}} \pm 0.07$ & $0.66^{\mathrm{a}} \pm 0.13$ \\
\hline Indian meat & $0.23^{\mathrm{a}} \pm 0.06$ & $0.39^{\mathrm{a}} \pm 0.09$ & $0.69^{\mathrm{a}} \pm 0.05$ & $0.87^{b} \pm 0.01$ & $0.34^{\mathrm{a}} \pm 0.04$ & $0.45^{\mathrm{a}} \pm 0.05$ & $0.59^{\mathrm{a}} \pm 0.03$ & $0.73^{\mathrm{a}} \pm 0.16$ \\
\hline
\end{tabular}

${ }^{\mathrm{a}-\mathrm{b}}$ Means with different superscripts within the same column significantly $(\mathrm{P}<0.05)$ different: * Values represent the mean \pm SE.

Table 3: Color and shear force values of burger patties and emulsion sausage processed from imported Brazilian and Indian chuck meat Treatments Storage period (months)

\begin{tabular}{|c|c|c|c|c|c|c|c|c|}
\hline & 0-time & $1^{\text {st }}$ month & $2^{\text {nd }}$ month & $3^{\text {th }}$ month & 0 -time & $1^{\text {st }}$ month & $2^{\text {nd }}$ month & $3^{\text {th }}$ month \\
\hline \multicolumn{4}{|c|}{ Burger patties $\left(-18^{\circ} \mathrm{C}\right)$} & \multicolumn{5}{|c|}{ Luncheon sausage $\left(4^{\circ} \mathrm{C}\right)$} \\
\hline $\mathrm{L}^{*}$ & & & & & & & & \\
\hline Brazilian meat & $40.84^{\mathrm{a}} \pm 0.09$ & $42.83^{\mathrm{a}} \pm 0.27$ & $42.94^{\mathrm{a}} \pm 0.18$ & $43.32^{\mathrm{a}} \pm 0.21$ & $63.49^{\mathrm{a}} \pm 0.29$ & $63.95^{\mathrm{a}} \pm 0.14$ & $64.44^{\mathrm{a}} \pm 0.09$ & $65.36^{\mathrm{a}} \pm 0.28$ \\
\hline $\begin{array}{l}\text { Indian meat } \\
\mathrm{a}^{*}\end{array}$ & $40.20^{\mathrm{a}} \pm 0.36$ & $40.56^{\mathrm{b}} \pm 0.19$ & 41.42 & $4163^{b}$ & $61.70^{\mathrm{b}} \pm 0.02$ & $62.69^{\mathrm{b}} \pm 0.06$ & 24 & $64.15^{\mathrm{b}} \pm 0.26$ \\
\hline Brazilian meat & $23.55^{\mathrm{a}} \pm 0.14$ & $21.94^{\mathrm{a}} \pm 0.05$ & 6 & 655 & $15.26^{\mathrm{a}} \pm 0.02$ & $15.00^{\mathrm{a}}$ & 14.8 & $14.45^{\mathrm{a}} \pm 0.06$ \\
\hline $\begin{array}{l}\text { Indian meat } \\
b^{*}\end{array}$ & $23.62^{\mathrm{a}} \pm 0.10$ & $22.07^{\mathrm{a}} \pm 0.22$ & 21. & 53 & $16.90^{\mathrm{b}} \pm 0.01$ & $16.75^{\mathrm{b}} \pm 0.07$ & \pm 0.01 & $15.02^{\mathrm{b}} \pm 0.11$ \\
\hline Brazilian meat & \pm 0 & $13.76^{\mathrm{a}} \pm 0.8$ & & & \pm 0 . & 0 & 13. & 0.30 \\
\hline $\begin{array}{l}\text { Indian meat } \\
\text { Shear force (kgf) }\end{array}$ & $14.27^{\mathrm{a}} \pm 0.02$ & $13.44^{\mathrm{a}} \pm 0.22$ & $12.56^{\mathrm{a}} \pm 0.73$ & $11.80^{\mathrm{a}} \pm 0.12$ & $12.43^{\mathrm{a}} \pm 0.01$ & $13.20^{\mathrm{a}} \pm 0.20$ & $13.46^{\mathrm{a}} \pm 0.25$ & $13.50^{\mathrm{a}} \pm 0.20$ \\
\hline Braz & $4^{\mathrm{a}} \pm 0.02$ & $1.04^{\mathrm{a}} \pm 0.10$ & 2 & 0.02 & \pm 0.01 & 0.3 & $0.36^{\mathrm{a}} \pm 0.01$ & $0.39^{\mathrm{a}} \pm 0.02$ \\
\hline Indian meat & $1.08^{\mathrm{b}} \pm 0.01$ & $1.15^{\mathrm{b}} \pm 0.10$ & $1.26^{\mathrm{b}} \pm 0.03$ & $1.36^{\mathrm{b}} \pm 0.01$ & $0.32^{\mathrm{b}} \pm 0.01$ & $0.34^{\mathrm{b}} \pm 0.01$ & $0.43^{b} \pm 0.01$ & $0.47^{b} \pm 0.01$ \\
\hline
\end{tabular}

$\overline{\mathrm{a}-\mathrm{b}}$ Means with different superscripts within the same column significantly $(\mathrm{P}<0.05)$ different: * Values represent the mean \pm SE.

Table 4: Sensory quality of burger patties and emulsion sausage processed from imported Brazilian and Indian chuck meat Treatments Storage period (months)

\begin{tabular}{|c|c|c|c|c|c|c|c|c|}
\hline & 0 -time & $1^{\text {st }}$ month & $2^{\text {nd }}$ month & $3^{\text {th }}$ month & 0 -time & $1^{\text {st }}$ month & $2^{\text {nd }}$ month & $3^{\text {th }}$ month \\
\hline \multicolumn{4}{|c|}{ Burger patties $\left(-18^{\circ} \mathrm{C}\right)$} & \multicolumn{5}{|c|}{ Luncheon sausage $\left(4^{\circ} \mathrm{C}\right)$} \\
\hline \multicolumn{9}{|l|}{ Appearance } \\
\hline Brazilian meat & $8.00^{\mathrm{a}} \pm 0.00$ & $7.66^{\mathrm{a}} \pm 0.33$ & $7.33^{\mathrm{a}} \pm 0.33$ & $7.00^{\mathrm{a}} \pm 0.57$ & $7.13^{\mathrm{a}} \pm 0.07$ & $6.95^{\mathrm{a}} \pm 0.05$ & $6.65^{\mathrm{a}} \pm 0.10$ & $6.48^{\mathrm{a}} \pm 0.09$ \\
\hline Indian meat & $7.66^{\mathrm{a}} \pm 0.33$ & $7.33^{\mathrm{a}} \pm 0.33$ & $7.33^{\mathrm{a}} \pm 0.33$ & $7.00^{\mathrm{a}} \pm 0.00$ & $6.50^{\mathrm{b}} \pm 0.03$ & $6.00^{\mathrm{b}} \pm 0.01$ & $6.00^{\mathrm{a}} \pm 0.04$ & $5.77^{\mathrm{a}} \pm 0.33$ \\
\hline \multicolumn{9}{|l|}{ Flavor } \\
\hline Brazilian meat & $8.00^{\mathrm{a}} \pm 0.00$ & $7.66^{\mathrm{a}} \pm 0.33$ & $7.00^{\mathrm{a}} \pm 0.00$ & $6.66^{\mathrm{a}} \pm 0.33$ & $7.33^{\mathrm{a}} \pm 0.33$ & $6.67^{\mathrm{a}} \pm 0.33$ & $6.33^{\mathrm{a}} \pm 0.33$ & $5.67^{\mathrm{a}} \pm 0.33$ \\
\hline Indian meat & $7.66^{\mathrm{a}} \pm 0.33$ & $7.33^{\mathrm{a}} \pm 0.66$ & $7.00^{\mathrm{a}} \pm 0.00$ & $7.00^{\mathrm{a}} \pm 0.57$ & $6.67^{\mathrm{a}} \pm 0.33$ & $6.20^{\mathrm{a}} \pm 0.43$ & $5.85^{\mathrm{a}} \pm 0.08$ & $5.08^{\mathrm{a}} \pm 0.12$ \\
\hline \multicolumn{9}{|l|}{ Tenderness } \\
\hline Brazilian meat & $8.00^{\mathrm{a}} \pm 0.00$ & $7.66^{\mathrm{a}} \pm 0.03$ & $7.00^{\mathrm{a}} \pm 0.00$ & $7.00^{\mathrm{a}} \pm 0.00$ & $7.58^{\mathrm{a}} \pm 0.02$ & $7.00^{\mathrm{a}} \pm 0.01$ & $6.33^{\mathrm{a}} \pm 0.33$ & $6.00^{\mathrm{a}} \pm 0.04$ \\
\hline Indian meat & $7.00^{\mathrm{b}} \pm 0.03$ & $7.00^{\mathrm{a}} \pm 0.02$ & $6.66^{\mathrm{a}} \pm 0.33$ & $6.00^{\mathrm{a}} \pm 0.00$ & $6.33^{\mathrm{b}} \pm 0.05$ & $6.00^{\mathrm{b}} \pm 0.04$ & $5.90^{\mathrm{a}} \pm 0.13$ & $5.80^{\mathrm{a}} \pm 0.17$ \\
\hline \multicolumn{9}{|l|}{ Juiciness } \\
\hline Brazilian meat & $8.00^{\mathrm{a}} \pm 0.00$ & $8.00^{\mathrm{a}} \pm 0.00$ & $7.66^{\mathrm{a}} \pm 0.33$ & $7.33^{\mathrm{a}} \pm 0.33$ & $7.33^{\mathrm{a}} \pm 0.33$ & $7.00^{\mathrm{a}} \pm 0.01$ & $6.33^{\mathrm{a}} \pm 0.33$ & $5.67^{\mathrm{a}} \pm 0.33$ \\
\hline Indian meat & $8.00^{\mathrm{a}} \pm 0.00$ & $7.00^{\mathrm{a}} \pm 0.57$ & $7.33^{\mathrm{a}} \pm 0.33$ & $6.66^{\mathrm{a}} \pm 0.33$ & $6.67^{\mathrm{a}} \pm 0.33$ & $6.55^{\mathrm{a}} \pm 0.17$ & $6.33^{\mathrm{a}} \pm 0.15$ & $5.66^{\mathrm{a}} \pm 0.33$ \\
\hline \multicolumn{9}{|c|}{ Overall acceptability } \\
\hline Brazilian meat & $8.00^{\mathrm{a}} \pm 0.00$ & $7.75^{\mathrm{a}} \pm 0.25$ & $7.25^{\mathrm{a}} \pm 0.14$ & $7.00^{\mathrm{a}} \pm 0.14$ & $7.38^{\mathrm{a}} \pm 0.02$ & $6.93^{\mathrm{a}} \pm 0.02$ & $6.33^{\mathrm{a}} \pm 0.18$ & $5.87^{\mathrm{a}} \pm 0.13$ \\
\hline Indian meat & $7.75^{\mathrm{a}} \pm 0.14$ & $7.28^{\mathrm{a}} \pm 0.26$ & $7.08^{\mathrm{a}} \pm 0.22$ & $6.70^{\mathrm{a}} \pm 0.10$ & $6.35^{\mathrm{b}} \pm 0.00$ & $6.10^{\mathrm{b}} \pm 0.04$ & $5.99^{\mathrm{a}} \pm 0.01$ & $5.42^{\mathrm{a}} \pm 0.12$ \\
\hline
\end{tabular}

sausages processed from Brazilian beef were 30.54, 8.66 and 16.55, respectively. Significant $(\mathrm{P}<0.05)$ reductions in SF values of burger patties and emulsion sausages processed from imported Brazilian meat when compared with those processed from Indian buffalo at 0-time and along the storage (Table 3). A higher SF value of emulsion sausage was recorded by Elbazidy et al. (2017).

The sensory scores of appearance, flavor, juiciness and overall acceptability of Brazilian or Indian burger patties showed non-significant $(\mathrm{P}>0.05)$ changes at 0 time and during frozen storage. However, the significant $(P<0.05)$ decreasing of tenderness score in burger patties processed from imported Brazilian meat was observed only at 0-time when compared with burger patties processed from Indian buffalo (Table 4). Appearance, tenderness and overall acceptability of emulsion sausages processed from imported Brazilian meat were higher significantly $(\mathrm{P}<0.05)$ only during the $1^{\text {st }}$ month of storage when compared with those processed from Indian meat. Meanwhile, the flavor and juiciness of emulsion sausages processed from imported Brazilian or Indian meat were not significantly $(\mathrm{P}>0.05)$ different at 0 -time and during chilling storage (Table 4). There was opposite correlation between the tenderness scores and the SF values, where higher tenderness scores were observed in formulas with lower SF values. The higher SF and lower tenderness scores for products processed from Indian meat were due to the higher collagen content which is responsible for its 
Table 5: Cooking characteristic of burger patties and emulsion stability of emulsion sausage processed from imported Brazilian and Indian chuck meat

\begin{tabular}{lcc}
\hline & Brazilian meat & Indian meat \\
\hline \multicolumn{2}{l}{ Cooking characteristic of burger patties } \\
Moisture retention \% & $58.24^{\mathrm{a}} \pm 0.95$ & $57.07^{\mathrm{a}} \pm 0.96$ \\
Fat retention \% & $93.65^{\mathrm{a}} \pm 0.81$ & $92.48^{\mathrm{a}} \pm 0.86$ \\
Diameter reduction \% & $14.92^{\mathrm{a}} \pm 1.32$ & $16.08^{\mathrm{a}} \pm 1.25$ \\
Shrinkage \% & $10.11^{\mathrm{a}} \pm 1.76$ & $16.50^{\mathrm{b}} \pm 1.27$ \\
Cooking loss \% & $8.00^{\mathrm{a}} \pm 0.32$ & $10.00^{\mathrm{b}} \pm 0.50$ \\
Emulsion stability of emulsion sausage & \\
TFR \% & $0.51^{\mathrm{a}} \pm 0.14$ & $1.50^{\mathrm{b}} \pm 0.04$ \\
Water \% & $0.03^{\mathrm{a}} \pm 0.01$ & $0.46^{\mathrm{b}} \pm 0.02$ \\
Gelatin and fat \% & $0.48^{\mathrm{a}} \pm 0.14$ & $1.03^{\mathrm{b}} \pm 0.01$ \\
\hline a b Means with different & superscripts within the same raw \\
significantly (P<0.05) different: $*$ Values represent the mean \pm SE.
\end{tabular}

toughness. The higher juiciness score for emulsion sausage processed from imported Brazilian meat was due to the higher moisture content of Brazilian meat. The moisture content might be considered an important determinant of juiciness as consequence of moisture released from the meat during chewing.

The results of cooking characteristic of burger patties processed from imported Brazilian and Indian meat are presented in Table 5. Moisture retention, fat retention and diameter reduction percentages were non-significantly $(P>0.05)$ differ between Brazilian and Indian burger patties. However, significant $(P<0.05)$ lower shrinkage percent and cooking loss were recorded for burger patties processed from imported Brazilian meat when compared with those processed from imported Indian meat. This result was in disagreement with Uriyapongson (2007) who found that there was no significant difference of cooking loss of burger patties processed from beef or buffalo. The positive correlation between cooking yield and fat retention was observed by Serdaroğlu and Değirmencioğlu (2004). Kassem and Emara (2010) recorded that cooking loss of patties processed from imported Brazilian meat was $17.83 \%$. Meanwhile, Bastos et al. (2014) observed that cooking loss and shrinkage \% of patties processed from Brazilian beef were 32.4 and $19.7 \%$, respectively.

Emulsion stability is guide for the amount of water and fat reserved by meat proteins. Therefore, the higher emulsion stability, the lower total fluid and fat released percentage after heat treatment. Lower emulsion stability was recorded for emulsion sausage processed from Indian meat when compared with those processed from imported Brazilian where, there significant $(P<0.05)$ increase in TFR $\%$, water release $\%$, gelatin and fat release $\%$ were recorded for emulsion sausages processed from Indian beef (Table 5). The values of emulsion stability for Brazilian emulsion sausage were in agreement with (Elbazidy et al., 2017) who found that TFR\% was $0.53 \%$. Moreover, Saad et al. (2016) observed that TFR\% and fat $\%$ of emulsion sausage processed from Brazilian beef were 4.90 and 2.27. The differences in emulsion stability was explained by several authors who found that many factors affect the emulsion stability such as the physical properties of protein fat matrix interaction and size of fat droplets (Lee et al., 1981), thickness of interfacial protein film and emulsion matrix integrity especially during thermal processing (Jones and Mandigo, 1982). In addition, the level of salt and polyphosphate which added in product formulation, emulsion $\mathrm{pH}$, type of meat used, protein level, fat type, water level, chopping temperature and machine used (Young et al., 2005).

\section{Conclusions}

From the current study it could be recommend the use of imported Indian meat after imported Brazilian meat for further processing meat products where, imported Indian meat is considered as another good option for raw meat materials. Therefore, this finding will give chance to the meat manufacturers to formulate good quality products from lower price meat source.

\section{Acknowledgments}

This study was financially supported from Faculty of Veterinary Medicine, Cairo University, Cairo, Egypt.

\section{REFERENCES}

Abdel-Aziz ME and Morsy NFS, 2015. Keeping quality of frozen beef patties by marjoram and clove essential oils. J Food Process Preserv, 39: 956-965. https://doi.org/ $10.1111 /$ jfpp. 12309.

Alakali JS, Irtwange SV and Mzer MT, 2010. Quality evaluation of beef patties formulated with bambara groundnut (Vigna subterranean L.) seed flour. Meat Sci, 85: 215-223. https://doi.org/10.1016/j.meatsci.2009.12.027.

Alkhanky SF, Ahmed MA and Mahmud MM, 2015. Physicochemical and sensory parameters as indices to evaluate the quality of imported frozen meat. M.V.Sc. Thesis, Meat Hygiene, Faculty of Veterinary medicine, Suez Canal University, Egypt.

AMSA "American Meat Science Association", 1995. Research guidelines for cookery, sensory evaluation and instrumental tenderness measurements of fresh meat. Chicago, IL, USA: American Meat Science Association.

AOAC "Association of Official Analytical Chemists", 2000 Official Methods of Analysis. Association of Official Analytical Chemists. $17^{\text {th }}$ Ed., Washington, DC, USA.

Bastos SC, Pimenta MESG, Pimenta CJ, et al., 2014. Alternative fat substitutes for beef burger: technological and sensory characteristics. J Food Sci Techn, 51(9): 2046-2053. https://doi.org/10.1007/s13197-013-1233-2.

Bauman RW, 2005. Microbiology, Pearson Education, San Francisco.published by pearson, Benjamin Cummings, 780 pages.

Colmenero FJ, Ayo MJ and Carballo J, 2005. Physicochemical properties of low sodium frankfurter with added walnut: Effect of transglutaminase combined with caseinate, $\mathrm{KCl}$ and dietary fiber as salt replacers. Meat Sci, 69: 781-788.

$\mathrm{Du} \mathrm{M}$ and Ahn DU, 2002. Effect of antioxidants on the quality of irradiated sausages prepared with turkey thigh meat. Poult Sci, 81: 1251-1256. https://doi.org/10.1093/ ps/81.8.1251.

Elbazidy MA, Emara MMT and Nouman TM, 2017. Quality of Traditional Egyptian Luncheon (Emulsion Type Sausage). Int J Chem Tech Res, 10: 315-320.

El-Magoli SB, Laroia S and Hansen PTM, 1996. Flavour and texture characteristics of low fat ground beef patties formulated with whey protein concentrate. Meat Sci, 42: 179-193. https://doi.org/10.1016/0309-1740(95)00032-1.

Gahruie HH, Hosseini SMH, Taghavifard MH, et al., 2017. Lipid oxidation, color changes, and microbiological quality of frozen beef burgers incorporated with shirazi thyme, cinnamon, and rosemary extracts. J Food Qual, 2017: 1-9. https://doi.org/10.1155/2017/6350156. 
Gracey JF, Collins DS and Huey RJ, 1999. Meat Hygiene. $10^{\text {th }}$ Ed., W. B. Saunders Co. Ltd., London.

Hughes H, Cofrades S and Tory DJ, 1997. Effect of fat level, oat fiber and carrageenan on frankfurters formulated with 5, 12 and 30\% fat. Meat Sci, 45: 273-281.

Jones KW and Mandigo RW, 1982. Effects of chopping temperature on the microstructure of meat emulsions. $\mathbf{J}$ Food Sci, 47: 1930-1935.

Kandeepan G, Anjaneyulu ASR, Kondaiah N, et al., 2009. Effect of age and gender on the processing characteristics of buffalo meat. Meat Sci, 83: 10-14. https://doi.org/ 10.1016/j. meatsci.2009.03.003.

Kassem MA and Emara MMT, 2010. Quality and acceptability of value-added beef burger. World J Dairy Food Sci, 5: 1420.

Kdous FSAM, Mona EY and Bayomey AM, 2016. Evaluation of new dried blends of fast processed luncheon meat. Middle East J Appl Sci, 6: 113-119.

Kearsley MW, El-Khatib L and Gunu COKA, 1983. Rapid determination of total volatile nitrogen in fish and meat. Association of Public Analysts, 21: 123-128.

Lee CM, Hampson JW and Abdollahi A, 1981. Effect of plastic fats on thermal stability and mechanical properties of fatprotein gel products. J Am Oil Chem Soc, 48: 983-987.

Mohamed ASI, Morshdy AEMA, Hussein MAM, et al., 2017. Quality assessment of imported frozen meat, M.V.Sc., Thesis, Food Hygiene and Control, Faculty of Veterinary Medicine, Zagazig University, Egypt.

Murphy RY, Marks BP and Grey BC, 1975. Comparison of methods for calculating retentions of nutrients in cooked foods. Agric Food Chem, 13(6): 1153-1157.
Ranken MD, 2000. Comminuted Meat Products. In: Handbook of Meat Product Technology. pp: 12-13. Black well Science, Oxford, USA.

Saad RS, Nouman TM and Emara MMT, 2016. Comparison between characteristics of mixer and bowel chopper meat batter. M.V.Sc. Thesis, Hygiene and Control of Meat and Its Products, Faculty of Veterinary Medicine, Cairo University.

Selim AEI, Hauka FI and Talib AH, 2015. Microbiological and chemical analyses of sausage and luncheon samples collected from some supermarkets in Mansoura city. J Agric Chem Biotech, Mansoura University, 6: 321-330.

Serdaroğlu M and Değirmencioğlu O, 2004. Effects of fat level $(5 \%, 10 \%, 20 \%)$ and corn flour $(0,2 \%, 4 \%)$ on some properties of Turkish type meatballs (Koefte). Meat Sci, 68 (2): 291-296. https://doi.org/10.1016/j.meatsci.2004.03.010

Shackelford SD, Wheeler TL and Koohmaraie M, 2004. Evaluation of sampling, cookery, and shear force protocols for objective evaluation of lamb Longissimus tenderness Anim Sci, 82: 802-807. https://doi.org/10.2527/2004. $823802 \times 10.2527 / 2004.823802 x$.

Shin H, Choi Y, Kim H, et al., 2008. Tenderization and fragmentation of myofibrillar proteins in bovine Longissimus dorsi muscle using proteolytic extract from Sarcodon aspratus. Food Sci Technol, 41: 1389-1395. https://doi.org/10.1016/j. lwt.2007.08.019.

Uriyapongson J, 2007. Comparison and improvement of chemical and physical characteristics of low- fat ground beef and buffalo meat patties at frozen storage. Ital J Anim Sci, 6(2): 1171-1174.

Young OA, Zhang SX, Farouk MM, et al., 2005. Effects of pH adjustment with phosphates on attributes and functionalities of normal and high pH beef. Meat Sci, 70: 133-139. 